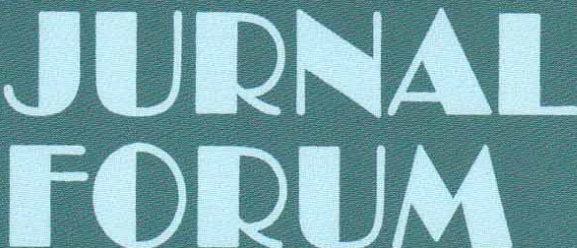

Volume 7 - Nomor 1

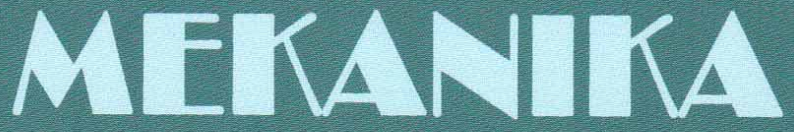

Mei 2018

ISSN : 2356-1491

PENGARUH FLY ASH DENGAN PENAMBAHAN CACAHAN KARET, SILICA FUME DAN SUPERPLASTICIZER TERHADAP BETON

TRI YUHANAH; TOMMY IDUWIN; BUDI WICAKSONO

PERILAKU STRUKTUR TOWER TRANSMISI TIPE SUSPENSION TERHADAP BEBAN ANGIN MUHAMMAD SOFYAN; DICKI DIAN PURNAMA; ABDUL ROKHMAN

IDENTIFIKASI PENYEBAB KECELAKAAN KERJA PADA PROYEK KONSTRUKSI BANGUNAN GEDUNG TINGGI

RETNA KRISTIANA; SLAMET

STUDI SIFAT MEKANIS TANAH MERAH DENGAN PENGUJIAN TRIAKSIAL REFFANDA KURNIAWAN RUSTAM

ANALISIS PENGARUH BESAR BUTIRAN AGREGAT KASAR TERHADAP KUAT TEKAN BETON NORMAL IKA SULIANTI; AMIRUDDIN; RIO SHAPUTRA; DARYOKO

ANALISIS BANJIR DAN TINGGI MUKA AIR PADA RUAS SUNGAI CILIWUNG STA 7+646 S/D STA $15+049$

IKA SARI DAMAYANTHI SEBAYANG; MELIANA PARLINA

ANALISIS KELAYAKAN PERENCANAAN PEMBANGUNAN JALAN PENGHUBUNG (MISSING LINK) ANTARA DESA SIKUR SAMPAI DESA PAOKMOTONG KABUPATEN LOMBOK TIMUR

DESSY ANGGA AFRIANTI; SIGIT IRFANSYAH; MEYRISSA PUTRI DEWANDARI 


\title{
PERILAKU STRUKTUR TOWER TRANSMISI TIPE SUSPENSION TERHADAP BEBAN ANGIN
}

\author{
MUHAMMAD SOFYAN \\ Program Studi Teknik Sipil, STT-PLN \\ E-mail :m.sofyan@sttpln.ac.id \\ DICKI DIAN PURNAMA \\ Program Studi Teknik Sipil, STT-PLN \\ E-mail :dicki@sttpln.ac.id \\ ABDUL ROKHMAN \\ Program Studi Teknik Sipil, STT-PLN \\ E-mail :abdulrokhman@sttpln.ac.id
}

\begin{abstract}
Abstrak
Kebutuhan pasokan listrik di Indonesia semakin besar seiring dengan pertumbuhan penduduk yang semakin tinggi. Hal ini memberikan dorongan kepada para pemangku kebijakan untuk memperluas pembangunan infrastruktur bidang ketenagalistrikan. Secara nasional, kebutuhan listrik terbesar adalah sektor industri, disusul sektor rumah tangga, usaha, dan umum. Dalam Penerapannya, struktur tower transmisi memiliki peran yang besar untuk mendistribusikan kebutuhan listrik pada umumnya. Struktur tower transmisi tergolong struktur rangka batang (Truss). Truss adalah struktur yang terdiri dari gabungan batang batang yang membentuk struktur berbentuk segitiga dan terhubung satu sama lain, serta dibebani pada jointjointnya. Dengan Konsep keseimbangan gaya dan desain code yang ada dapat ditentukan kapasitas tower serta respon struktur ketika memikul beban-beban primerkhususnya beban angin.
\end{abstract}

Kata Kunci : Tower transmisi, Truss, Beban Angin

\begin{abstract}
The need for electricity supply in Indonesia is getting bigger along with the higher population growth. This gives encouragement to stakeholders to expand infrastructure development in the electricity sector. Nationally, the biggest demand for electricity is industrial sector, followed by household, business, and general sectors. In its application, the tower transmission structure has a major role to distribute the electricity needs in general. Transmission tower structure is classified as Truss structure. The truss frame is a structure consisting of a combination of rods forming triangular structures connected to each other, and encumbered in their joints. With the concept of balance of style and design of the existing code can be determined the capacity of tower and the response of the structure when carrying the primary loads, especially wind loads.
\end{abstract}

Keywords : Ttransmission Tower, Truss, Wind Load

\section{Latar Belakang}

Kebutuhan pasokan listrik di Indonesia semakin semakin besar seiring dengan pertumbuhan penduduk yang semakin tinggi. Hal ini memberikan dorongan kepada para pemangku kebijakan untuk memperluas pembangunan infrastruktur bidang ketenagalistrikan.Secara nasional, kebutuhan listrik terbesar adalah sektor industri, disusul sektor rumah tangga, usaha, dan umum. Namun, jika ditinjau per wilayah pola kebutuhan listrik akan berubah, dimana semakin ke wilayah timur Indonesia, semakin besar kebutuhan listrik sektor rumah tangga dibanding sektor industri. Hal ini dikarenakan masih rendahnya rasio elektrifikasi saat ini dan terbatasnya jumlah industri ${ }^{[4]}$.

Pada tahun 2016 pemerintah telah merilis peraturan khusus mengenai percepatan pembangunan infrastruktur ketenagalistrikan yang tertuang pada Peraturan Presiden Republik Indonesia Nomor 4 Tahun 2016.

Dalam Sudut pandang ketekniksipilan, salah satu komponen fisik infrastruktur ketenagalistrikan adalah konstruksi tower Saluran Udara Tegangan Ekstra Tinggi (SUTET) dan Saluran Udara Tegangan Tinggi (SUTT), yang mana mudah dirakit terutama didaerah pegunungan dan jauh dari jalan 
raya serta dengan biaya yang relatif lebih murah. Dalam terminologi mekanika teknik, struktur tower tergolong struktur rangka batang (Truss). Rangka batang (truss) adalah struktur yang terdiri dari gabungan batang batang yang membentuk struktur berbentuk segitiga dan terhubung satu sama lain, serta dibebani pada joint-jointnya. Dengan Konsep keseimbangan gaya dan desain code yang ada dapat ditentukan kapasitas tower dalam memikul bebanbeban primer.

Penelitian mengenai tower transmisi telah banyak dilakukan oleh banyak peneliti di berbagai negara. Beberapa diantaranya yang mempelajari kegagalan struktur tower akibat intensitas beban angin yang tinggi ${ }^{[1]}$. Tahun 2014 dilakukan Studi Komparatif desain tower yang menggunakan ASCE code dan Indian Code ${ }^{[3]}$. Tahun 2010 dilakukan Studi Experimental terkait perilaku korosi pada tower transmisi ${ }^{[7]}$.

Sebagian besar struktur tower transmisi material strukturalnya menggunakan baja. Sifat Baja yang memiliki kuat tarik tinggi sangat memungkinkan untuk memikul gaya aksial tarik yang bereaksi pada tower akibat pembebanan, namun material baja memiliki berat volume yang cukup besar, sehingga pabrikasi elemen struktur pembentuk konstruksi tower dibuat dengan ukuran penampang yang relatif kecil atau langsing.

\section{Landasan Teori}

\section{Saluran Udara Tegangan Tinggi}

Komponen utama dari Fungsi struktur pada sistem transmisi SUTT / SUTET adalah Tiang (Tower).Tiang adalah konstruksi bangunan yang kokoh untuk menyangga / merentang konduktor penghantar dengan ketinggian dan jarak yang aman bagi manusia dan lingkungan sekitarnya dengan sekat insulator.

Tiang/ Tower Menurut Fungsi:

1. Tiang penegang (tension tower)

Tiang penegang disamping menahan gaya berat juga menahan gaya tarik dari konduktorkonduktor saluran Udara Tegangan Tinggi (SUTT) atau Ekstra Tinggi (SUTET). Tiang penegang terdiri dari:

a. Tiang sudut (angle tower)

Tiang sudut adalah tiang penegang yang berfungsi menerima gaya tarik akibat perubahan arah Saluran Udara Tegangan Tinggi (SUTT) atau Ekstra Tinggi (SUTET).

b. Tiang akhir (dead end tower)

Tiang akhir adalah tiang penegang yang direncanakan sedemikian rupa sehingga kuat untuk menahan gaya tarik konduktorkonduktor dari satu arah saja. Tiang akhir ditempatkan di ujung Saluran Udara Tegangan Tinggi (SUTT) atau Ekstra
Tinggi (SUTET) yang akan masuk ke switch yard Gardu Induk.

2. Tiang penyangga (suspension tower)

Tiang penyangga untuk mendukung/ menyangga dan harus kuat terhadap gaya berat dari peralatan listrik yang ada pada tiang tersebut.

3. Tiang penyekat (section tower)

Yaitu tiang penyekat antara sejumlah tower penyangga dengan sejumlah tower penyangga lainnya karena alasan kemudahan saat pembangunan (penarikan konduktor), umumnya mempunyai sudut belokan yang kecil.

4. Tiang transposisi

Adalah tiang penegang yang berfungsi sebagai tempat perpindahan letak susunan phasa konduktor-konduktor Saluran Udara Tegangan Tinggi (SUTT) atau Saluran Udara Tegangan Ekstra Tinggi (SUTET).

5. Tiang portal (gantry tower)

Yaitu tower berbentuk portal digunakan pada persilangan antara dua saluran transmisi yang membutuhkan ketinggian yang lebih rendah untuk alasan tertentu (bandara, tiang crossing).Tiang ini dibangun di bawah saluran transmisi eksisting.

6. Tiang kombinasi (combined tower)

Yaitu tower yang digunakan oleh dua buah saluran transmisi yang berbeda tegangan operasinya.

\section{Teori Tekuk Elastik}

Pengetahuan tentang perilaku tekuk merupakan hasil dari rangkaian penelitian yang telah lama dilakukan sebelumnya. Sejarah mencatat, penelitian tentang tekuk pada kolom diawali oleh Euler sekitar tahun 1744. Kolom yang dievaluasi dianggap lurus sempurna (teoritis), penampang prismatis, tumpuan sendi-sendi, gaya tekan tepat diberikan pada sumbu aksial kolom (aksial murni) dan relatif langsing sedemikian sehingga akan mengalami tekuk pada kondisi tegangan elastis (belum leleh). Beban tekuk atau beban kritis didefinisikan sebagai berikut.

$P_{c r}=\frac{\pi^{2} E I}{L^{2}}$

dimana E adalah modulus elastis, I adalah momen inersia arah terjadinya tekuk, dan L adalah panjang kolom. Kecuali dalam format beban, bisa juga format tegangan kritis, dimana $\boldsymbol{\sigma}_{\boldsymbol{c r}}=$ $\boldsymbol{P}_{\text {cr }} /$ Asehingga

$\sigma_{c r}=\frac{\pi^{2} E}{(L / r)^{2}}$

Jika kondisi tumpuan bukan sendi-sendi, beban atau tegangan kritisnya dapat didekati sebagai berikut. 


$$
P_{c r}=\frac{\pi^{2} E I}{K L^{2}}
$$

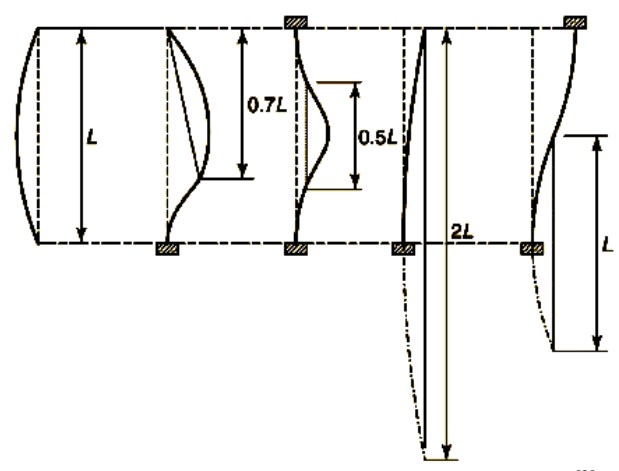

Gambar 1. Panjang efektif kolom secara visual ${ }^{[2]}$

\section{Beban Angin}

\section{a. Pada Konduktor}

Beban Angin pada konduktor dianggap bekerja pada setengah bentang konduktor yang ditransfer ke cross arm.

$F_{a}=n . L . d$ (analisa terapan)

Dimana :

n : Jumlah Konduktor

L : Panjang Bentang

D : Diamter Konduktor

$\mathrm{Fa}$ : Beban Angin pada konduktor

Pada Body Tower

Beban Angin desain Untuk Struktur Menara rangka Batang dapat dihitung dengan Persamaan Berikut ${ }^{[8]}$$$
F=q_{z} G C_{f} A_{f}
$$

\section{Beban Konduktor (Kabel)}

Kondisi Normal

Beban mekanis Konduktor

$F_{c}=n \cdot L \cdot W$

Dimana

N : Jumlah Konduktor

L : Panjang Rentang Konduktor Saat Normal

$\mathrm{W}$ : Berat $(\mathrm{N} / \mathrm{m})$

Cf dihitung dengan persamaan berikut ${ }^{[8]}$

$$
C_{f}=4 \epsilon^{2}-5.9 \in+4
$$

Dimana

$\mathrm{F}$ : Beban angin $(\mathrm{Kg})$

qz : Tekanan Velositas

$\mathrm{G}$ : Faktor Efek tiupan Angin
Cf : Koefisien Gaya

Af : Luas terproyeksi tegak Lurus terhadap angina

\section{Metodologi Penelitian}

\section{Gambaran Umum Penelitian}

Dalam Penelitian ini akan dimodelkan tower transmisi tipe suspension. Ketinggian tower yang disesuaikan dengan kondisi lapangan. Ketinggian tower yang akan dianalisa adalah ketinggian $26 \mathrm{~m}$. Untuk Perencanaan batang tarik dan tekan metode yang dipakai adalah metode LRFD/AISC 2010. Analisa Pembebanan mekanis mengacu pada Buku 1 PLN tahun 2010 dan SNI. Alat bantu yang digunakan dalam desain dan analisis struktur adalah program komputer analisis struktur yang mampu menganalisa perilaku tekuk elastis.

Pengumpulan data dan informasi tentang struktur tower SUTT yang dijadikan objek pada penelitian ini berupa data sekunder maupun data primer. Data sekunder yang berupa berat elemen struktur,berat elemen elektrikal dan ukuran penampang profil baja yang telah dipabrikasi. Sedangkan data-data pendukung lainnya diperoleh dari buku pedoman pemeliharaan SUTT PT PLN dan Buku Pedoman PLN.

\section{Prosedur Penelitian}

Alat bantu yang digunakan dalam desain dan analisis struktur adalah program komputer analisis struktur yang mampu menganalisa perilaku tekuk elastis. Dengan menggunakan software akan dilakukan prosedur mengevaluasi dan menganalisa model struktur tower.

Langkah langkah pemodelan dan analisa struktur adalah sebagai berikut ;

1. Pemodelan Geometri Struktur 3D

2. Definisikan propertis Struktur (Material dan Penampang), Load cases(Beban mati, Hidup dan Angin),dan Load Combination

3. Definisikan Buckling Load dan efek p-delta.

4. Input beban mati dan beban hidup kemudian lakukan running program

5. Jika tidak terdapat warning Tampilkan pola mode/ragam akibat tekuk.

6. Tampilkan Drift dan gaya batang dari setiap mode

7. Lakukan komparasi hasil respons struktur (Drift, Gaya batang) berdasarkan variasi geometri struktur yang ada 


\section{Konfigurasi Geometris Struktur}

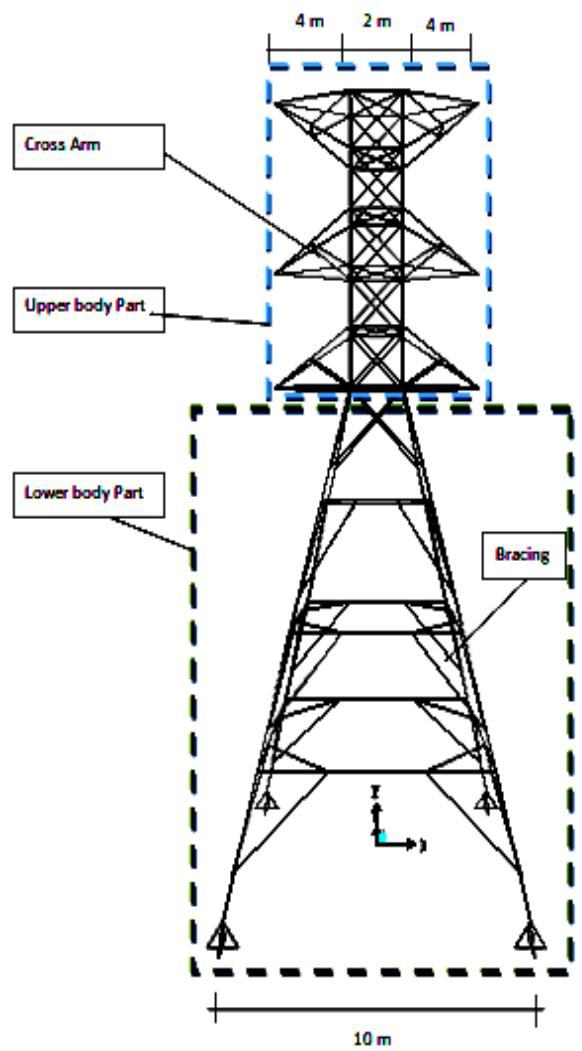

Gambar 3. Deskripsi Geometri Tower

Tabel 1. Daftar Penampang batang tarik/tekan yang digunakan

\begin{tabular}{|c|c|c|}
\hline No & Sub- unit elemen struktur & Jenis profil baja \\
\hline 1 & Bracing & Siku \\
\hline 2 & Cross arm & Siku \\
\hline 3 & Upper body & Siku \\
\hline 4 & Leg of lower body & Siku \\
\hline
\end{tabular}

Bagian-bagian tower meliputi Lower Body, Upper Body, Cross Arm dan Bracing.

\section{Data-Data Propertis Material Rangka Tower}

Jenis baja yang digunakan adalah baja BJ 37 dengan tegangan leleh karakteristik $\mathrm{f}_{\mathrm{y}}=210 \mathrm{MPa}$, tegangan putus $\mathrm{f}_{\mathrm{u}}=370 \mathrm{MPa}$, modulus elastis = $200.000 \mathrm{MPa}$, modulus geser $\mathrm{G}=80.000 \mathrm{MPa}$, Nisbah Poisson $\mu=0.3$

\section{Preliminary Data standar Beban}

Preliminary Data standar Beban

Tipe Tower : Suspension $150 \mathrm{kV}$

- Berat Konduktor ACSR diameter 24,12 mm : $1151 \mathrm{~kg} / \mathrm{km}$ (SPLN 41-7 : 1981)

- Insulator Long Rod : $7 \mathrm{Kg}{ }^{[5]}$

- Kekuatan Hembus Angin : $80 \mathrm{daN} / \mathrm{m} 2^{[5]}$

- Panjang Gawang : $450 \mathrm{~m}$

\section{Analisis Dan Pembahasan}

Analisa Beban Konduktor (Kabel)

Kondisi Normal

Beban mekanis Konduktor

$F_{c}=n \cdot L \cdot W$

$F_{c}=2.225 .1151$

$F_{c}=517,95 \mathrm{~kg}$

\section{Analisa Beban Angin}

Pada Konduktor

Beban Angin pada konduktor dianggap bekerja pada setengah bentang konduktor yang ditransfer ke cross arm.

$F_{a}=n \cdot L \cdot d$

$F_{a}=2.225 .24,12$

$F_{a}=403,2 \mathrm{~kg}$

Pada Body Tower

Berdasarkan Hasil perhitungan beban angin ${ }^{[8]}$ didapatkan hasil pada Tabel 2 berikut :

Tabel 2. Beban angin pada body tower

\begin{tabular}{|c|c|c|c|c|c|c|c|c|c|c|}
\hline Elevasi & $\begin{array}{c}\text { As } \\
\text { (Luas } \\
\text { Bidang } \\
\text { kontak) } \\
\left(\mathrm{m}^{2}\right)\end{array}$ & $\begin{array}{c}\text { Ag } \\
(\text { Luas } \\
\text { (Lruto) } \\
\left(\mathrm{m}^{2}\right)\end{array}$ & $\varepsilon$ & Cf & $\mathrm{G}$ & $\mathrm{Qz}$ & $\begin{array}{c}\text { Af } \\
\left(\mathrm{m}^{2}\right)\end{array}$ & $\begin{array}{c}\mathrm{F} \\
(\mathrm{Kg})\end{array}$ & $\begin{array}{c}\text { LH } \\
(\mathrm{m})\end{array}$ & $\begin{array}{c}\text { LV } \\
(\mathrm{m})\end{array}$ \\
\hline 4 & 0.8364 & 16.8 & 0.049786 & 3.716179 & 0.85 & 800 & 0.8364 & 211.3584 & 8 & 4.2 \\
8 & 0.7344 & 12.6 & 0.058286 & 3.669703 & 0.85 & 800 & 0.7344 & 183.262 & 6 & 4.2 \\
12 & 0.6324 & 8.4 & 0.075286 & 3.578486 & 0.85 & 800 & 0.6324 & 153.8864 & 4 & 4.2 \\
16 & 0.306 & 2 & 0.153 & 3.190936 & 0.85 & 800 & 0.306 & 66.397 & 2 & 2 \\
18 & 0.306 & 2 & 0.153 & 3.190936 & 0.85 & 800 & 0.306 & 66.397 & 2 & 2 \\
20 & 0.306 & 2 & 0.153 & 3.190936 & 0.85 & 800 & 0.306 & 66.397 & 2 & 2 \\
22 & 0.306 & 2 & 0.153 & 3.190936 & 0.85 & 800 & 0.306 & 66.397 & 2 & 2 \\
24 & 0.306 & 2 & 0.153 & 3.190936 & 0.85 & 800 & 0.306 & 66.397 & 2 & 2 \\
26 & 0.306 & 2 & 0.153 & 3.190936 & 0.85 & 800 & 0.306 & 66.397 & 2 & 2 \\
\hline
\end{tabular}

LV merupakan Panjang batang vertical tiap segmen bodi tower yang ditinjau dan LH merupakan Panjang Batang Horisontal.Nilai beban Angin yang telah dihitung kemudian di proyeksikan ke Body Tower.

\section{Skema Pembebanan Tower}

\section{Beban akibat berat konduktor}

Beban konduktor sebesar $517.95 \mathrm{~kg}$ di proyeksikan seperti pada gambar 4. Dimana arah gaya mengikuti arah gravitasi dan tepat berada di joint cross arm sebagai beban terpusat. 


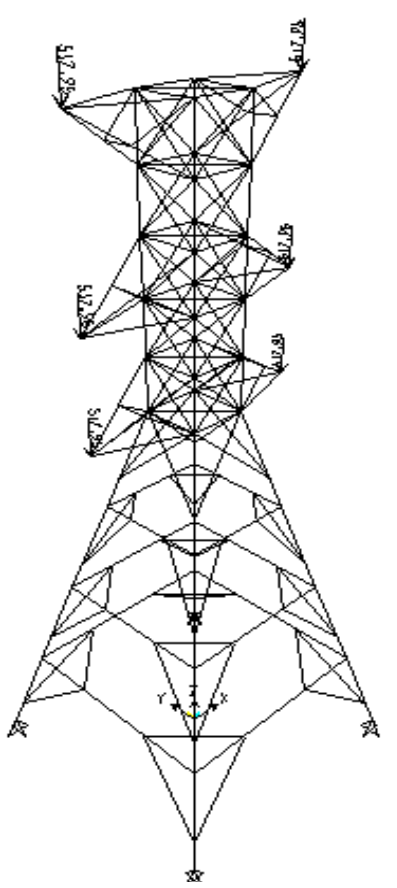

Gambar 4. Beban akibat berat konduktor

\section{Beban akibat berat Insulator}

Beban akibat berat insulator sebesar $14 \mathrm{~kg}$ di proyeksikan seperti pada gambar 5. Dimana arah gaya mengikuti arah gravitasi dan tepat berada di joint cross arm sebagai beban terpusat. Dalam kasus ini beban insulator berimpit dengan beban konduktor

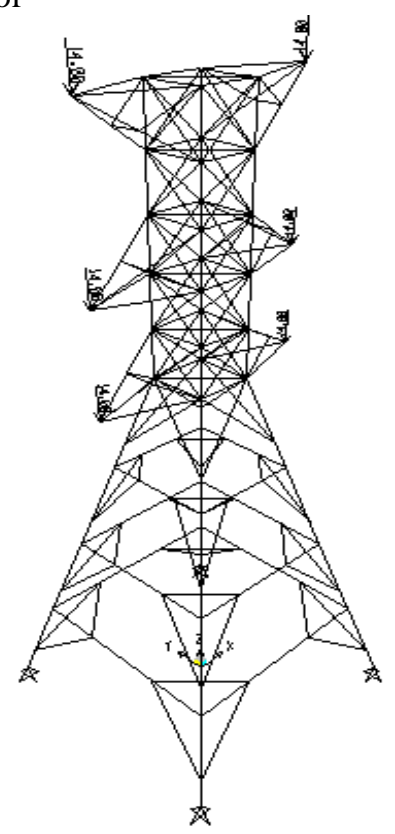

Gambar 5. Beban akibat berat insulator

Khusus untuk kasus Beban angin pada konduktor sebesar $403.2 \mathrm{~kg}$ di proyeksikan seperti pada gambar 6. Arah gaya beban angin berbeda dengan konduktor dan insulator namun bekerja pada joint yang sama.

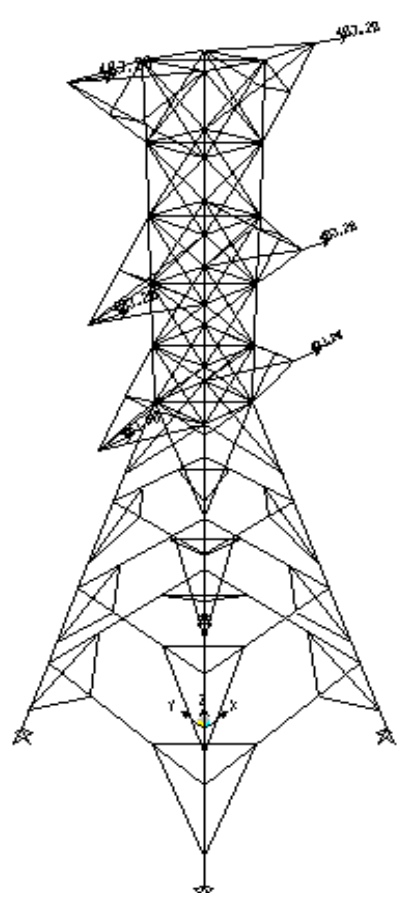

Gambar 6. Beban akibat angin pada konduktor

Beban angin yang bekerja pada permukaan konduktor memiliki asumsi yang berbeda dengan beban angin yang secara langsung terproyeksi pada body tower.Beban yang bekerja secara langsung pada body tower dikalkulasi berdasarkan SNI 1723 2013. Hasil Perhitungan diperoleh seperti pada tabel 2. Beban-beban angin yang dihitung dianggap bekerja berdasarkan elevasi yang telah ditentukan seperti pada gambar 7 .

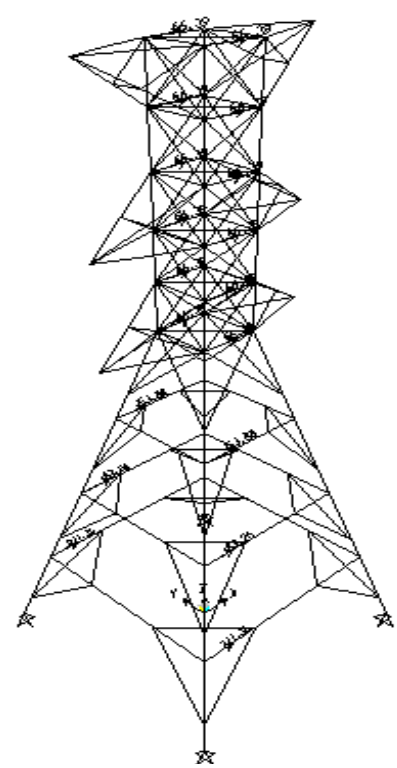

Gambar 7. Beban akibat angin pada Body Tower 


\section{Kapasitas Penampang}

Dilakukan perhitungan kapasitas penampang yang merupakan preliminary design.Karena diharapkan kapasitas pikul penampang telah cukup untuk memikul beban menurut kriteria desain yang ada.Hasil desain penampang disajikan pada tabel 3 dan secara grafis pada gambar 8 .

Tabel 3. $P$-M Ratio maksimum dan Profil Penampang yang terpakai

\begin{tabular}{|l|c|c|}
\hline \multicolumn{1}{|c|}{$\begin{array}{c}\text { Sub- unit Elemen } \\
\text { Strultral }\end{array}$} & Profil (Angle) & $\begin{array}{c}\text { P-M Ratio } \\
\text { Maksimum }\end{array}$ \\
\hline $\begin{array}{l}\text { Leg (Lower Body) } \\
\begin{array}{l}\text { Leg bracing of lower } \\
\text { body }\end{array}\end{array}$ & L6 4 × 5/16 & 0.869 \\
$\begin{array}{l}\text { Horizontal member of } \\
\text { lower body }\end{array}$ & L3 $\times 3 \times 3 / 16$ & 0.198 \\
$\begin{array}{l}\text { Horizontal member of } \\
\text { upper body }\end{array}$ & L2 $\times 2 \times 1 / 8$ \\
$\begin{array}{l}\text { Vertical member of } \\
\text { upper body }\end{array}$ & L2 $25 \times 3 / 16$ \\
$\begin{array}{l}\text { Bracing of upper body } \\
\text { Cross arm }\end{array}$ & L3 $\times 3 \times 3 / 16$ & 0.928 \\
\hline
\end{tabular}

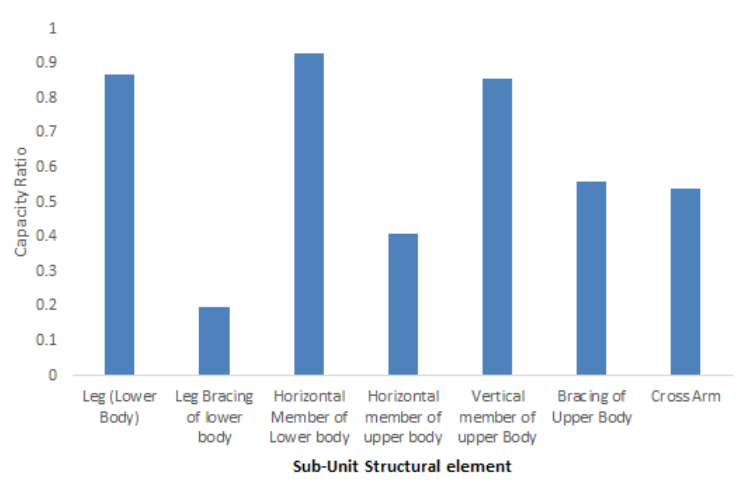

Gambar 8. Rasio Kapasitas Penampang Struktural

Pada gambar 8 terlihat bahwa $P-M$ ratio terbesar berada pada bagian kaki tower (Lower Body leg) yaitu sebesar 0.928 dan yang terkecil pada bagian bracing kaki tower yaitu sebesar 0.198. Dengan melihat angka tersebut efisiensi penampang pada bagian lower body paling optimal dan ukuran penampang bracing masih bisa diperkecil lagi.

\section{Deformasi Tower}

Deformasi Pada tower dapat terjadi dari berbagai kondisi. Vektor Gaya memiliki pengaruh yang besar terhadap deformasi struktur.Dalam penelitian ini pola deformasi yang ditinjau akibat beban angin pada konduktor, beban angin pada body tower serta kombinasi beban mati dan beban angin. Hasil analisa menunjukkan pola deformasi seperti pada gambar 9 .

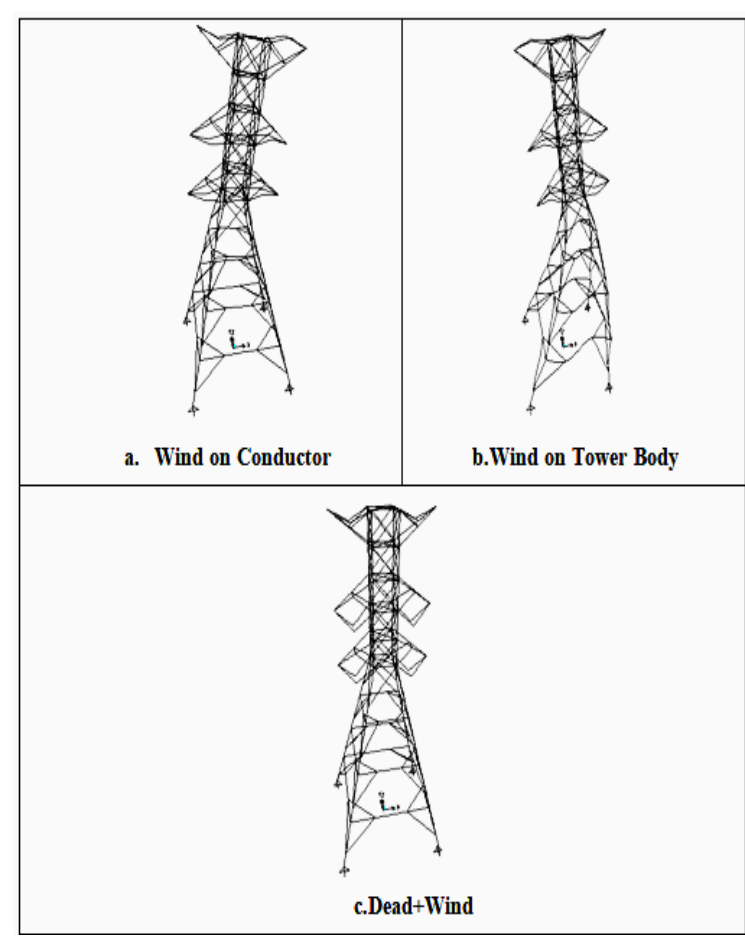

Gambar 9. Deformed Shape

Pada gambar 9 terlihat bahwa pola deformasi pada ketiga kondisi pembebanan memiliki perilaku yang berbeda. Deformasi arahlateral terjadi akibat beban angin. Sedangkan deformasi dalam arah gravitasi ditunjukkan pada kondisi ke 3 (Gambar 9 c. Pada kondisi tersebut beban gravitasi menjadi lebih dominan.

Nilai Deformasi Perpindahan struktur tower disajikan pada table 4 dan secara grafis pada gambar 10.

Tabel 4. Perpindahan/Displacement pada body tower

\begin{tabular}{|c|c|c|c|}
\hline \multirow{2}{*}{$\begin{array}{c}\text { Elevasi } \\
(\mathrm{m})\end{array}$} & \multicolumn{3}{|c|}{ Perpindahan } \\
\cline { 2 - 4 } & $\mathrm{W}_{1}(\mathrm{~mm})$ & $\mathrm{W}_{2}(\mathrm{~mm})$ & $\mathrm{D}+\mathrm{W}$ \\
\hline 0 & 0 & 0 & 0 \\
\hline 4 & 0.36 & 5.7 & -0.478 \\
\hline 8 & 0.72 & 8.56 & -0.952 \\
\hline 12 & 1.36 & 8.56 & -1.76 \\
\hline 16 & 0.97 & 5.6 & 1.1 \\
\hline 18 & 3.3 & 4.01 & 4.4 \\
\hline 20 & 6.23 & 2.59 & 7.9 \\
\hline 22 & 9.4 & 1.3 & 12.3 \\
\hline 24 & 12.8 & 0.1 & 16.6 \\
\hline 26 & 16.58 & -1.07 & 21.7 \\
\hline
\end{tabular}

$\mathrm{W}_{1}$ adalah angin pada konduktor, $\mathrm{W}_{2}$ angin pada body tower dan $\mathrm{D}+\mathrm{W}$ Adalah Kombinasi beban mati dan angin. 


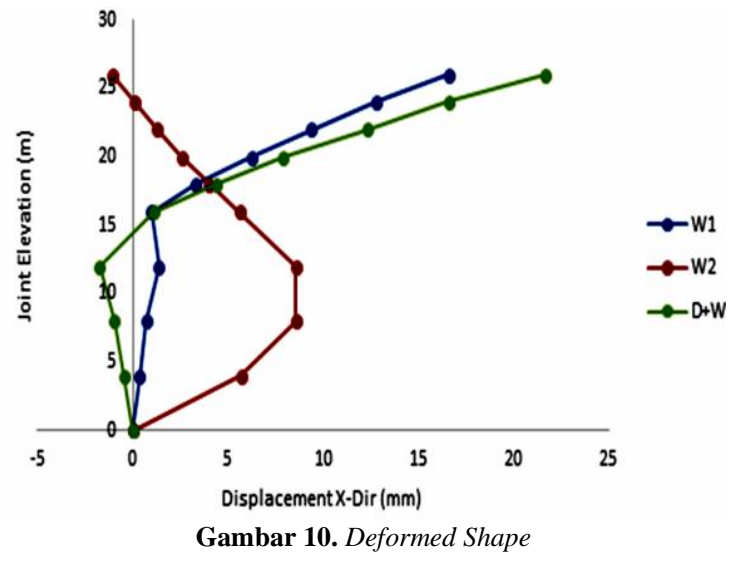

Gambar 10. Menunjukkan bahwa perpindahan terbesar dalam arah lateral terhadap body tower terjadi akibat kombinasi beban mati dan angin yaitu sebesar $21.7 \mathrm{~mm}$. Perpindahan akibat beban angin pada konduktor ternyata jauh lebih besar dari perpindahan akibat angin pada body tower dengan Selisih $48.37 \%$.

\section{Kesimpulan}

1. Pada gambar 8 terlihat bahwa $\mathrm{P}-\mathrm{M}$ ratio terbesar berada pada bagian kaki tower (Lower Body leg) yaitu sebesar 0.928 dan yang terkecil pada bagian bracing kaki tower yaitu sebesar 0.198. Dengan melihat angka tersebut efisiensi penampang pada bagian lower body paling optimal dan ukuran penampang bracing masih bisa diperkecil lagi.

2. Perpindahan akibat beban angin pada konduktor ternyata jauh lebih besar dari perpindahan akibat angin pada body tower. Dengan Selisih 48. $37 \%$.

\section{Ucapan Terima Kasih}

Ucapan Terima Kasih sebesar-besarnya peneliti ucapkan kepada STT-PLN Jakarta sebagai perguruan tinggi yang mendanai penelitian
ini.Semoga hasil penelitian ini bisa bermanfaat untuk kemajuan ilmu pengetahuan dan teknologi khususnya dalam bidang energi dan ketenagalistrikan.

\section{Daftar Pustaka}

[1] Ahmad, Shakeel., Ansari Md. E., “ Response of transmission towers subjected to tornado loads" The Seventh Asia-Pacific Conference on Wind Engineering, November 8-12, 2009, Taipei, Taiwan.

[2] Galambos,2008.Structural Stability of Steel: Concepts and Applications for Structural Engineers.John Wiley \& sons, INC.

[3] Jatwa, Harsha et al,2014 . "Comparative Study of Indian and ASCE Codes Provision for Design of Transmission Tower". International Journal of Innovations in Engineering and Technology (IJIET)

[4] Muchlis dkk, 2003.Proyeksi kebutuhan Listrik PLN tahun 2003 s/d 2020.Seminar Pengembangan Sistem Kelistrikan dalam Menunjang Pembangunan Nasional Jangka Panjang Proyeksi Kebutuhan.

[5] PT PLN Persero, 2010.Buku 1 PLN, Jakarta, Indonesia

[6] PT PLN Persero, 2014.Buku Pedoman Pemeliharaan Saluran Udara tegangan tinggi SUTT/SUTET. Dokumen Nomor : P D M / S $\mathrm{T} \mathrm{T} / 10: 2014$

[7] S.Christian Johnson 1 G.S.Thirugnanam "Experimental study on corrosion of transmission line tower foundation and its rehabilitation" International Journal Of Civil And Structural Engineering ISSN 0976 - 4399 Volume 1, No 1, 2010

[8] SNI 1723.2013. Beban Minimum Untuk Perancangan Bangunan gedung dan Struktur Lain, BSN, Jakarta, Indonesia 